\title{
Bioecology of coral reef in Panjang Island of Central Java Indonesia
}

\author{
Suryono ${ }^{1 *}$, Ambariyanto Ambariyanto $^{1}$, Munasik $^{1}$, Diah Permata Wijayanti ${ }^{1}$, Raden Ario $^{1}$, \\ Ibnu Pratikto ${ }^{1}$, Nur Taufiq-Spj ${ }^{1}$, Syahrial V. Canavaro ${ }^{1}$, Tiara Anggita ${ }^{2}$, \\ Bayu Kreshna Adhitya Sumarto ${ }^{3}$, Justin Cullen 4
}

\author{
${ }^{1}$ Department of Marine Science, Faculty of Fisheries and Marine Science, Diponegoro University \\ 2Department of Oceanography, Faculty of Fisheries and Marine Science, Diponegoro University \\ Jl. Prof. H. Soedharto, SH, Tembalang Semarang. 50275 Indonesia \\ ${ }^{3}$ Tropical Biosphere Research Center University of the Ryukyus \\ Nishihara, Okinawa, Japan \\ ${ }^{4}$ Graduated from Tasmania University \\ Launceston 23 Magenta Sq Amaroo, ACT 2914 Australia \\ Email: suryono1960@gmail.com
}

\begin{abstract}
Coral reefs currently are suffered from natural factors along with increasing anthropogenic activity. Panjang Island, a small reef island located in Jepara Regency, may also be experiencing such conditions. Therefore, this work was aimed to observe the condition of the coral cover of Panjang Island. Line intercept transect was applied to survey the coral cover and mortality index from fourteen stations. Insitu data consisted of the bottom substrate composition of the reefs and the physical parameters of the sea. The secondary data, i.e. coral reef area maps from 2001 to 2019 were taken from Landsat Image 7 and 8, data of wind were obtained from www.ogimet.com, while tidal data were collected from BMKG. The bathymetry was determined from the Geospatial Information Agency data, salinity global analysis forecast Phy 001.024 (CMEMS). Sea surface temperature (SST), and chlorophyll-a distribution were analyzed using ENVI software. The result showed that Panjang Island has a poor to the moderate condition of hard coral. Two out of six categories of abiotic and dead coral were found to be high. The mortality index of coral was in the high category (average 0.52). During research periods the sea waters were characterized by high sea surface temperature (29.34-30.94 $\left.{ }^{\circ} \mathrm{C}\right)$, chlorophyll-a was also tended to be high (0-2.65 $\left.\mathrm{mg}^{-3} \mathrm{~m}^{-3}\right)$, and an average of salinity was high $32 \%$. The weak currents came to all sides of the island, therefore the coral reef was not exposed to extreme currents. The waves came from the east, then the energy decreases after being blocked by coral reefs on the eastern side of the island, so that coral reefs in the northeast and south sides were safer to be exposed. The results suggest that hydrodynamic ecology directly or indirectly affected the percentage of coral cover and mortality index at the reefs of Panjang Island.
\end{abstract}

Keywords: Physical parameters, Anthropogenic, Insitu, Line Intercept Transect, Manta Tow, Abiotic

\section{Introduction}

Coral reefs are one of the oldest reef systems on earth (Pandolfi,2011). Hidaka (2016) stated that coral reefs comprise a symbiotic system that coexists among coral algae, ecosystems, landforms, and humans at various levels. As a marine ecosystem, coral reefs are very vulnerable to degradation (Pratchett et al., 2013; Vo et al., 2013). The degradation has resulted from a combination of natural and human activities (anthropogenic) factors. Pratchett et al. (2014) and Wisha et al. (2019) stated that coral reefs have a long history of degradation due to human activities. Research has been conducted on several factors that cause degradation of coral reefs, such as climate change (Baker et al., 2008; Munday et al., 2009; Ateweberhan et al., 2013), pollution (Burke et al., 2011; Riegl and Purkis 2012), sedimentation (Wolanski et al., 2004; Fabricius, 2005; Wooldridge, 2009), destructive fishing (Jackson et al., 2001; Chabanet et al., 2016; Fox et al., 2005; Hughes et al., 2007; Caras and Pasternak, 2009), coral mining (Caras and Pasternak, 2009), marine tourism, and development coastal area (Yusuf, 2007; Mimura, 2008; Vo et al., 2013). Research on the ecological conditions of coral reef ecosystems has been carried out in several previous studies. Perera-Valderrama et al. (2016) conducted an assessment of the condition of coral reef ecosystems in two marine conservation areas using indicators of ecology, mortality, and disease. Chabanet et al. (2016) monitored the condition of coral reefs with time-series data in water areas that are free of pressure from fishery activities. Korpinen and Andersen (2017), Crain et al. (2008); and Magris et al. (2018) conducted studies on the pressure and 
cumulative impacts of human activities on coral reef ecosystems. Borja et al. (2012) conducted a study on the integration of the impact of human pressure and environmental parameters in a time series. Fabinyi (2008) conducted a study of diving tourism and fisheries in conservation areas.

Bioecology is the study of the interaction of the living organism with its environment (Rifa'i, 2004). Bioecological factors are complex and do not act individually but are a unity that interacts and works together simultaneously. They are also dynamic because they change over time (Tjitrosomo et al., 2010). Tjahyo et al. (2000) stated that bioecology concerns biological and ecological aspects. Bioecological research in many areas has been carried out by several previous researchers. Suharti et al. (2018) have examined the Chaetodontidae species composition, distribution, and their bioecology in Togean Islands National Park, Central Sulawesi. Muhammad et al. (2013) have examined the bio-ecological application of macrobenthos as an indicator of pond fertility levels. Ardli et al. (2015) examined changes in mangrove bioecology in mangrove restoration in Segara Anakan, Cilacap.

Coral is very sensitive to changes in environmental factors, especially Sea Surface Temperature (SST) (Corvianawatie and Abrar, 2018). Water quality conditions that can not be tolerated by corals are thought to be able to inhibit the rate of growth and the process of resilience (Osborne et al., 2011; Corvianawatie and Abrar, 2018). Giyanto et al. (2017) stated that in the ideal ecology of coral reef, SST is in the range of $27-29^{\circ} \mathrm{C}$ which is ideal for the growth and development of the corals, and the relationship with chlorophyll-a concentration. Nybakken (1992) said that chlorophyll-a is one indicator to determine the level of seawater quality. Current and wave are hydrophysical ecology factors that interact and control coral growth (Dollar, 1982; Halid et al., 2016). Understanding the biology of corals and different sources of disturbance were needed to understand coral reefs resilience (Osborne et al., 2011). Panjang Island is a small island surrounded by coral reefs (Munasik et al., 2020). Preliminary identification of bioecology of coral reef in Panjang Island has been conducted by Suryono et al. (2017), and reported that the biology aspect of corals in terms of coral cover was in the medium category, and suspected that due to many stressors that caused degradation of coral reefs. The study was conducted to determine the coral reef condition according to the percentage of live coral cover, mortality index (MI), and its relation to hydrodynamic ecological factors which is important information for the conservation of the reefs.

\section{Material and Methods}

The study was conducted in the waters of Panjang Island, Java Sea, about 1,5 nautical miles or $2,8 \mathrm{~km}$ from the mainland of Jepara (Suraji et al., 2015; Munasik et al., 2020). Panjang Island is located on the north coast of Central Java in the position of $110^{\circ} 37^{\prime} 30^{\prime \prime}-110^{\circ} 38^{\prime} 0^{\prime \prime}$ East Longitude and $6^{\circ} 34^{\prime} 15^{\prime \prime}-6^{\circ} 34^{\prime} 45^{\prime \prime}$ South Latitude. The island is highly influenced by the Northeast Monsoon from November to February, which brings heavy rainfall and storms (Wong 1993). During that time, ecological pressures are increased. The study used a survey research method (Nazir, 2005). Samples were taken from fourteen (14) sampling stations. Coral reefs ecosystem was monitored using the line intercept transect (LIT) method (English et al., 1997). The percent cover of the benthic lifeform was analyzed using a lifeform-based software program with UNEP standards that were applied in ASEAN-Australia (Rahmat et al., 2001). The coral mortality was calculated using the formula from Gomez et al. (1994). Mortality Index (MI) is divided into four categories, namely: MI value ranges from $0-0.249=$ low; $0.25-0.499=$ medium; $0.50-0.749=$ high; and $0.75-1=$ very high category.

The secondary data, i.e. coral reef area maps from 2001 to 2019 were taken from Landsat Image 7 and 8, data of wind were obtained from www.ogimet.com, while tidal data were collected from BMKG. The bathymetry was determined from the Geospatial Information Agency data, salinity global analysis forecast Phy 001.024 (CMEMS). Sea surface temperature (SST), and chlorophyll-a distribution were analyzed using ENVI software. The change of coral reef area was built and overlayed based on basic data of Landsat 7 and 8 satellite imagery of 2001, 2005, 2010, 2015, and 2019. The GIS method is employed to finalized the changes map of the coral reef area from 2001 to 2019 and was done according to the method developed by Green et al. (2000), Arsjad et al. (2005), and Siregar (2010).

Ground checks were carried out using the manta tow method to measure the distribution of coral reefs (Kenchington, 1978; Moran et al., 1990; English et al., 1997). Furthermore, the map of the area of coral reefs in the year of observation was overlaid according to Adininggar et al. (2016), and Titi and Zainuddin (2017) to determine the changes in coral reefs areas. Waves were measured using the Acoustic Doppler Current Profiler (ADCP) instrument and the values were analyzed using the mathematical calculation method (Apuke, 2017). High significant wave (Hs) and significant period (Ts) obtained from wind data conversion to Hs value and Ts with DNS method (Sugianto et al.,2017). Currents were obtained by using ACDP equipment (Yuningsih and 
Achmad, 2011), then analyzed by quantitative method (Amirullah et al., 2014). The results of current and wave modeling were then generating, inputted by processing data using excel, entered into ArcGIS together with the results map of the change coral reef area 2001-2019, to obtain a map of the change coral reef area concerning the direction and velocity of the current, also the direction and wave height.

\section{Result and Discussion}

\section{Biology of coral reefs}

The percentage of live coral cover from 14 stations showed a range between $5-40 \%$ (Table 1 ). Abiotic, dead coral (DC), and hard coral (HC) substrates were three out of six categories found with high percentages. The substrate categories of sponges/others (OT), soft coral (SC), and macroalgae (MA) found in a low percentage. The abiotic substrate was found to dominate in almost every station. The most common type of abiotic substrate in Panjang island is rubble (RB). Overall, the percentage of hard coral $(\mathrm{HC})$ cover was not dominant. However, when compared to the percentage of macroalgae and sponge/other (OT) which are competitors of corals, then the percentage of hard coral $(\mathrm{HC})$ still dominates in coral reefs of the waters of Panjang Island.

The result showed that hard coral $(\mathrm{HC})$ cover was in the medium category indicated that a poor to the moderate condition of hard coral $(\mathrm{HC})$. There was a high percentage of dead coral cover (DC) and abiotic substrate compared to the percentage of hard coral cover ( $\mathrm{HC})$. Two factors that may cause damage to coral reefs in Panjang Island are natural and anthropogenic. The dominant factor that occurred is presumed due to human activity impact (anthropogenic) compared to natural factors (Toruan et al., 2013; Suryono et al., 2017; Lutfi et al., 2019a; 2019b).

The value of the mortality index (IM) of coral reefs in Panjang Island is shown in Figure 1 . The average mortality index is in the high category $(0,52)$. Based on substrate cover percentage and index mortality, it is found that the coral reef in Station 1 is the worst with a mortality Index (MI) is 0.80 . The low mortality index of coral reefs was found at Stations 4 , 14 , and $5(0.33,0.40$, and 0.42 , respectively).

Table 1. Percentage cover of the substrate category of coral reef in Panjang Island of Central Java Indonesia

\begin{tabular}{ccccccc}
\hline Station & $\begin{array}{c}(\%) \\
\text { Hard Coral (HC) }\end{array}$ & $\begin{array}{c}(\%) \\
\text { Dead Coral } \\
(\mathrm{DC})\end{array}$ & $\begin{array}{c}(\%) \\
\text { Soft Coral (SC) }\end{array}$ & $\begin{array}{c}\text { (\%) Abiotic } \\
(\%)\end{array}$ & $\begin{array}{c}(\%) \\
\text { Macro Algae } \\
(\text { MA) }\end{array}$ & $\begin{array}{c}\text { Sponge/ } \\
\text { Others (OT) }\end{array}$ \\
\hline 1 & 10 & 40 & 0 & 39.95 & 10 & 0.05 \\
2 & 20 & 20 & 0 & 49.9 & 10 & 0.10 \\
3 & 20 & 20 & 25 & 29.27 & 5 & 0.73 \\
4 & 20 & 10 & 20 & 49.47 & 0 & 0.53 \\
5 & 40 & 30 & 5 & 14.8 & 10 & 0.20 \\
6 & 40 & 40 & 0 & 19.27 & 0 & 0.73 \\
7 & 30 & 20 & 10 & 35.0 & 5 & 0.36 \\
8 & 30 & 30 & 20 & 19.55 & 0 & 0.45 \\
9 & 20 & 20 & 10 & 39.75 & 10 & 0.25 \\
10 & 20 & 30 & 10 & 29.7 & 10 & 0.30 \\
11 & 5 & 10 & 0 & 84.78 & 0 & 0.22 \\
12 & 30 & 40 & 0 & 19.34 & 10 & 0.66 \\
13 & 20 & 30 & 9.59 & 30 & 10 & 0.41 \\
14 & 30 & 20 & 10 & 30 & 9.41 & 0.59 \\
\hline
\end{tabular}

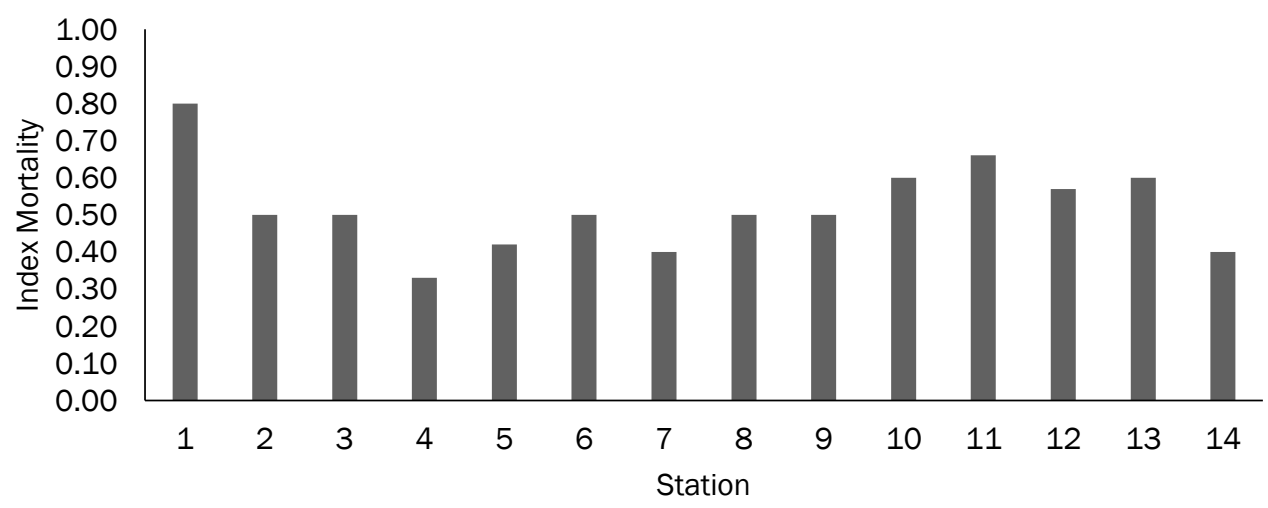

Figure 1. Mortality Index (MI) of coral reef in Panjang Island of Central Java Indonesia 
However, when considered the percentage of live coral cover, the coral reef in Station 5 is in better condition compared to other stations. The coral mortality that occurred at all stations was presumed due to pressure that occurs related to IUU (IIlegal, Unreported, Unregulated) fishing and destructive fishing activities. The IUU Fishing activity is activity fisheries that are illegal, unreported, and not following the regulations (Arsyad et al., 2014). The waters of Panjang island are one out of three fishing grounds for the fisherman in the Jepara Area (Kunarso et al., 2016).

The most dominant natural factor that influences the degradation of coral reefs in Panjang Island was sedimentation, sea surface temperature (SST), and salinity. The two most influential anthropogenic factors were destructive fishing (Ministry of Marine Affairs and Fisheries, 2006) and the increase in tourism activities (Badan Pusat Statistik, 2017). Fishing activities are carried out in destructive ways, for example by using toxic cyanide, electricity, and non-environmentally friendly fishing gear such as a net or local name i.e. Cantrang net that is still found operated in Panjang Island (Personal inspection). In addition, fishing activities by stepping on coral reefs are still happen (trampling and gleaning) (Suryono et al., 2017). Coral mining by coastal community for building materials is found to have accelerated the process of coral reef degradation in Panjang Island (Bappeda Kabupaten Jepara, 2003; Badan Lingkungan Hidup dan Energi Kabupaten Jepara, 2007). The mining of corals causes increasing water turbidity and will inhibit coral growth, even the death of coral reefs (Ariani, 2006). If activities of coral mining are continued, it is not only threatening the existence of the coral reef ecosystem but also inhibits the natural recovery process (Edrus et al., 2010). The damage of the coral reefs ecosystem is a threat to the survival of marine life and it takes a very long time to recover (Nugraha, 2019).

\section{Ecology of coral reefs}

The results of sea surface temperature (SST) and chlorophyll-a data are presented in Table 2, and the distribution of salinity can be seen in Figure 2 . During the research period, seawater was characterized by high SST, high chlorophyll-a production. and high salinity (32\%o)

Table 2. Distribution of sea surface temperature (SST) and chlorophyll-a of coral reef in Panjang Island of Central Java Indonesia In 2020

\begin{tabular}{cccc}
\hline No & Month & Sea surface temperature $(\mathrm{SST})\left({ }^{\circ} \mathrm{C}\right)$ & Chlorophyll-a $\left(\mathrm{mg} \cdot \mathrm{m}^{-3}\right)$ \\
\hline 1 & January & 30.81 & 1.82 \\
2 & February & 30.94 & 0.54 \\
3 & March & 29.91 & 0.73 \\
4 & April & 30.77 & 0.68 \\
5 & May & 31.07 & 1.44 \\
6 & June & 30.35 & 1.64 \\
7 & July & 29,69 & 2.01 \\
8 & August & 29.34 & 1.29 \\
9 & September & 30.03 & 2.66 \\
10 & October & 30.71 & 0.56 \\
11 & November & 30.81 & 0 \\
12 & December & 31.52 & 0.95 \\
\hline
\end{tabular}

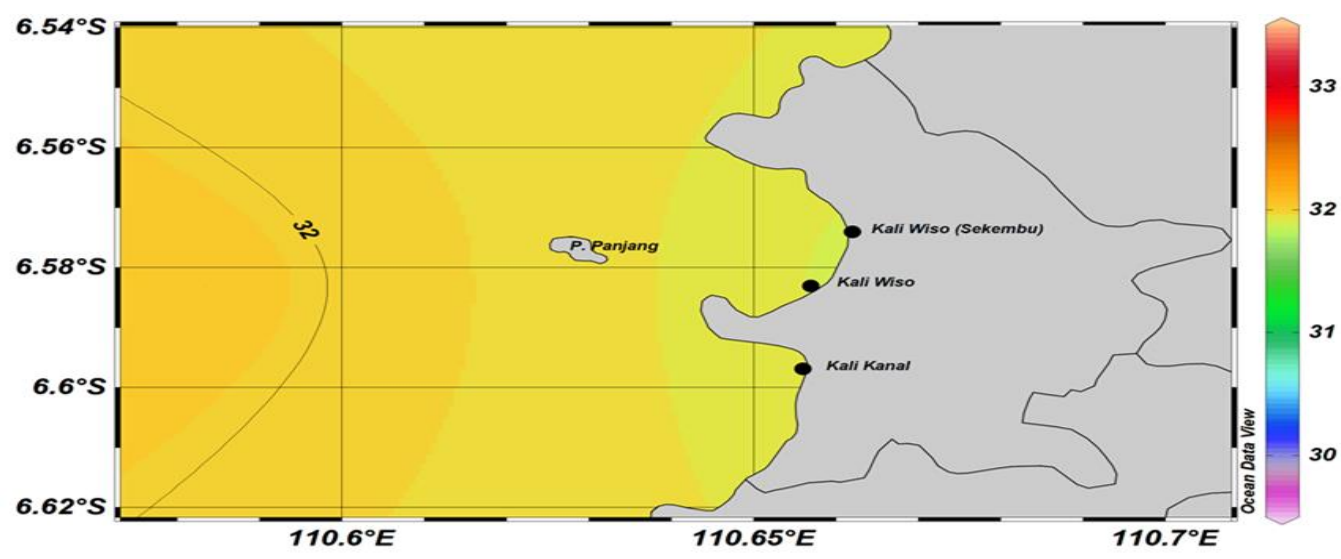

Figure 2. Distribution of salinity of coral reef in Panjang Island of Central Java Indonesia In 2020 

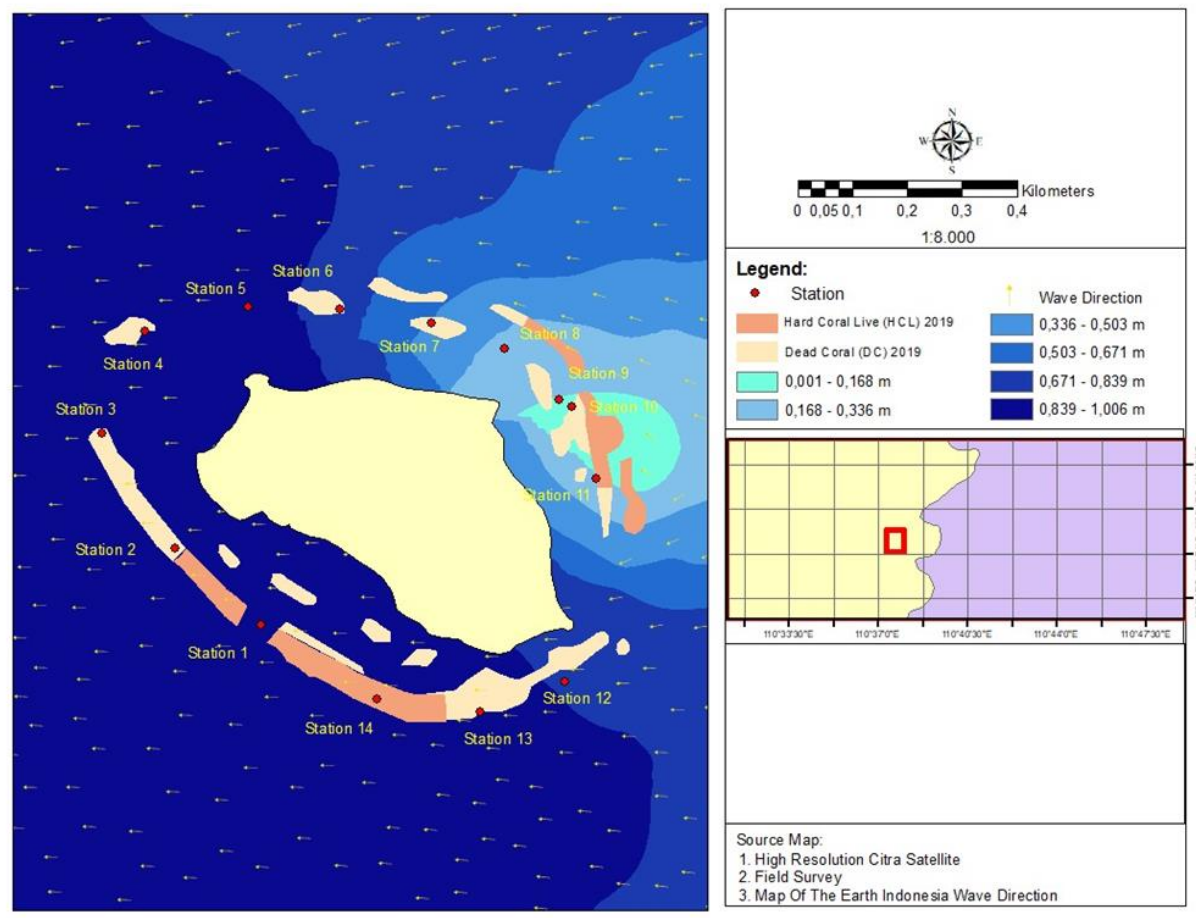

Figure 3. The change of coral reefs area and wave hydrodynamic of coral reef in Panjang Island of Central Java Indonesia In 2019

Overlay results of coral reef area changes from 2001 to 2019 and the hydrodynamics of waves and currents are presented in Figures 3 and 4 . The coral reefs in Panjang Island had undergone extensive changes, decreased to $45.742 \%$, with a change rate of 0.302 Ha.y-1 from 2001-2019. In 2001, the distribution of live coral reefs was seen on the northeast, east, south, and west sides of Panjang Island, then reduced their area, until they were left on the northeast and south sides of the island in 2019.

The lowest wave height is $0.001-0.168 \mathrm{~m}$, and the highest wave is $0.84-1.01 \mathrm{~m}$. The waves come from the east then the energy decreases after being blocked by coral reefs on the eastern side of the island, so that coral reefs on the south side of the island are safer from wave exposure (Figure 3.). The lowest currents speed ranges were 0.00-0.16 m.s $\mathrm{s}^{-1}$, while the highest currents speed ranges were 0.00$1.00 \mathrm{~m} . \mathrm{s}^{-1}$. The currents come from all directions of the island so the coral reef of Panjang Island was exposed to currents. Unfortunately, the speed of the currents is weak, so that the coral reefs are not extremely exposed to the currents (Figure 4.).

Nybakken (1992) states that chlorophyll-a is an indicator to determine the level of seawater fertility. Vollenweider et al. (1998) stated that the chlorophyll-a concentration $\leq 5 \mathrm{mg} \cdot \mathrm{m}^{-3}$ was categorized as mesotrophic and eutrophic waters. The high distribution of chlorophyll-a concentrations in Panjang Island is due to a large supply of nutrients that came from the run-off of the mainland (Hartuti et al., 2004). Chlorophyll-a can also be used as an indication of coral reef health (Limbu and Kyewalyanga, 2015). Chlorophyll-a concentration was above $0.2 \mathrm{mg} \cdot \mathrm{m}^{-3}$ showed the presence of sufficient planktonic to sustain the fishery commercial (Widodo, 1999).

Sea surface temperature (SST) is another important factor in the distribution of coral reefs. An ideal temperature for the coral reef was in the range of $27-29^{\circ} \mathrm{C}$ (Siburian and Mega, 2019). Coral reefs grow and develop optimally in waters with an average annual temperature of $23-25^{\circ} \mathrm{C}$ Giyanto et al., (2017) mentioned that the ideal temperature for coral reef growth is in the range of $27-29{ }^{\circ} \mathrm{C}$, this warm temperature has a relationship with the chlorophyll-a concentration. The average water temperature of coral reefs in the optimum range for stony coral growth is $28-29^{\circ} \mathrm{C}$ (Supriharyono, 2007).

The salinity of the waters of Panjang Island was lower than the seawater standard for marine biota, which is 33-34\%o (KLH, 2004). Coral reefs can only live in the waters with a normal salinity of $32-35 \%$ (Swart, 2013). Coral reefs do not live in waters that receive regular freshwater runoff from large rivers, which leads to low salinity (Anonymous, 2019). These factors play an important role in the continuity of the photosynthetic process by zooxanthellae found in 

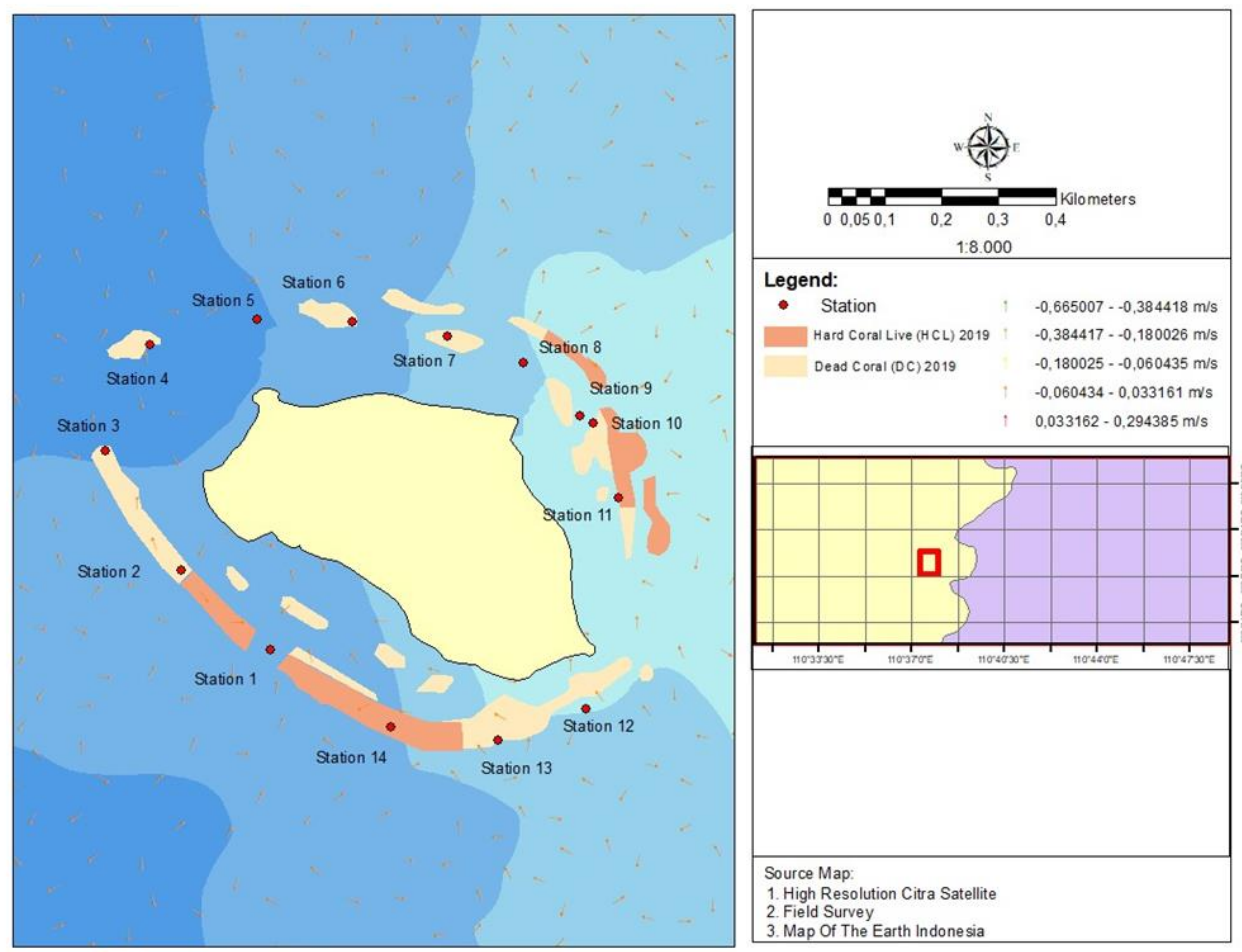

Figure 4. The change of coral reef area and current hydrodynamic of coral reef in Panjang Island of Central Java Indonesia In 2019

coral tissue. The environmental requirements must be met for the optimal growth and development of coral reefs. Change of ecology of coral reefs either directly or indirectly can affect coral reef conditions. Pollution from the mainland will instantly change the quality of water so that it can damage the reef coral (Wibawa and Luthfi, 2017).

The level of exposure to coral reefs by waves strength is quite high, this is presumed as one factor that causing the damage and decline of hard coral (HC) coverage in Panjang Island. Rachmawati et al., (2018) reported wave heights above $1 \mathrm{~m}$ that damage to coral reefs in the waters of Panjang Island, especially during the rainy season (December-March) as the waters of Panjang Island is part of the northern Java sea, therefore influenced by western monsoons season from South China Sea (Susiati et al., 2011; Suryono et al., 2017). Purwanto et al. (2020) reported a wave height of 0.251-0.792 $\mathrm{m}$ with a wave period of 3.663-4.717 sec. in Lirang Island, Southwest Maluku. Supiyati (2008) stated that in the east monsoon the dominant waves occurred with a height of 1.0-3.0 m. Kurniawan et al. (2011) also reported that the wave height reaches $1.25-2.5 \mathrm{~m}$. Widhiarno and Yati (2016) conducted wave forecasting in Indramayu and reported that the value $(H s)$ was as high as 0.4-0.5 m. Arianti et al. (2017), reported significant wave height occurred in July, from $0.21 \mathrm{~m}$ to $1.47 \mathrm{~m}$ in Palu Bay waters. Hidayat et al. (2013) reported that the waves on Parang Island Karimunjawa have a transitional wave type (medium) with a significant height of $0.231 \mathrm{~m}$ and wave period of 1,578 seconds. All the study results mentioned above confirmed that wave height and wave periods affect the structure and growth of coral reefs. The current was another factor that influenced coral reef growth (Adjeroud, 1997; Richards et al., 2012; Wenger et al., 2016; Guan et al., 2015). Current hydrodynamic was one of the physical oceanography factors that can affect coral reefs health (Monismith, 2007) so that the distributions of coral reefs were influenced by the current (Halid et al., 2016). Currents affected the growth of coral reefs (Dollar, 1982), and are significant factors that determine the construction of the coral reef ecosystem (Halid et al., 2016; Giyanto et al., 2017). Currents are sources of disturbance that provide risks to coral reef resilience (Osborne et al., 2011). Currents are needed to provide water flow which carries food and oxygen intake and protect coral reef from the influence of sedimentation. Current carry new plankton to feed coral polyps (Nybakken, 1992), and cleaning coral reef structure from silt (Burke, 2011). Nurulita et al. (2018) investigated the movement of the coral larva (planula) Acropora in the Islands of Seribu, the Island of Biawak, and Islands of Karimunjawa based on oceanographic conditions, and showed that the current pattern and velocity was affected by tidal conditions. Apart from that current effect on structure 
and growth of a coral reef, the distribution and attachment of coral larvae were driven by current, as has been reported by Munasik et al. (2006), on Study the role of Current on coral Planula in Panjang Island Jepara. So that the currents are a factor that plays a role in the recruitment process in coral reef resilience (Adjeroud et al., 2016; Rogers, 2013; Markey et al.,2016; Nurita et al.,2018)

\section{Conclusion}

The bottom substrate cover in Panjang Island waters has poor to the moderate condition of hard coral (HC). Abiotic, dead coral (DC), and hard coral (HC) bottom substrates were three of the six categories found with high percentages. The abiotic substrate was dominated in almost every station. The mortality index of coral reefs is in the medium category with an average of 0.52. During periods of research, Panjang Island waters were characterized by higher sea surface temperature (SSTs) i.e. 29.34$3094^{\circ} \mathrm{C}$ and the chlorophyll-a were between 0 mg.m ${ }^{-}$ 3 to $2.65 \mathrm{mg} \cdot \mathrm{m}^{-3}$, and an average of salinity was 32 $\%$. The direction of currents come from all side of the island so that all sides of the coral reef are exposed to currents. However, the speed of the currents is weak, so that the coral reefs are not extremely exposed by the strong currents. The direction of waves comes from the east of the island then the energy decreases after being blocked by coral reefs on the eastern side of the island, so that coral reefs in the northeast and south sides of the island are safer to be exposed. Hydrodynamic ecology directly or indirectly affects the biology of coral reefs in the waters of Panjang Island, Java Sea.

\section{Acknowledgment}

Our deepest gratitude is given to the Faculty of Fisheries and Marine Science Diponegoro University on Non-APBN research, provided financial support for this research with research contract number 76/UN7.5.10.2/PP/2021. We would also like to thanks Annisa and Adhim, who helped analyze the data in this research.

\section{References}

Adininggar, F.W., Suprayogi, A. \& Wijaya, A.P. 2016. Pembuatan peta potensi lahan berdasarkan kondisi fisik lahan menggunakan metode weighted overlay. J. Geodhesi, 5(2): 136-146 .

Adjeroud, M. 1997. Factors influencing spatial patterns on coral reefs around Moorea, French Polynesia. Mar. Ecol. Prog. Ser., 159: 105-114.

Adjeroud M., Kayal, M. \& Penin, L. 2016. Importance of Recruitment Processes in the Dynamics and
Resilience of Coral Reef Assemblages. In S. Rossi (ed.), Marine Animal Forests. Springer International Publishing Switzerland. p 1-21. doi: 10.1007/978-3-319-17001-5_12-1

Amirullah. N., Sugianto, D.N. \& Indrayanti, E. 2014. Kajian Pola Arus Laut Dengan Pendekatan Model Hidrodinamika Dua Dimensi Untuk Pengembangan Pelabuhan Kota Tegal. J. Oceanograp., 3(4): 671-682.

Anonymous. 2019 Reduced salinity of seawater wreaks havoc on coral chemistry: North Queensland floods could cause 'freshwater bleaching' of GBR. Science Daily. ARC Centre of Excellence in Coral Reef Studies.

Ardli, E.R., Widyastuti, A. \& Yani, E. 2015. Kajian Perubahan Bioekologi pada Restorasi Ekosistem Mangrove di Segara Anakan Cilacap. Biosfera, 32(1): 19-28. doi: 10.20884/1.mib. 2015.32.1. 291.

Titi, A \& Zainuddin, M. 2017. Pemetaan Potensi Kekeringan Lahan se-pulau Batam menggunakan Teknik Sistem Informasi Geografis (SIG) dan Penginderaan Jauh. Majalah Geografi Indonesia, 31(1): 91-94.

Apuke, O.D. 2017. Quantitative Research Methods: A Synopsis Approach. Arabian J. Business and Manag. Rev. 6(11): 40-47. doi: 10.12816/00 40336

Arsjad, A.B.S.M., Siswantoro, Y., Saputro, G.B., Hartini, S. \& Yuwono, D.M. 2005. Pedoman Survei dan Pemetaan Terumbu Karang. Bogor (ID): Pusat Survei Sumberdaya Alam Laut-Badan Koordinasi Survei dan Pemetaan Nasional (PSSDAL-BAKOSURTANAL).

Arsyad, M., Ristiana, E. \& Ritonga, I.R. 2014. Coverage Analysis on Column Substarte of Coral Reef Ecosystem at Coastal Garden Area of Derawan Island's Waters at Kecamatan Batu Putih, Kabupaten Berau. J. IImu Perikanan Tropis, 20(1): 34-43.

Ateweberhan, M., Feary, D.A., Kreshavmurthy, S. \& Chen, A. 2013. Climate change impacts on coral reefs: Synergies with local effects, possibilities for acclimation, and management implications. Mar. Poll. Bull., 74(2): 526-539, doi: 10.1016/ j.marpolbul.2013.06.011.

Borja, A., Dauer, D.M. \& Gremare, A. 2012. The importance of setting targets and reference conditions in assessing marine ecosystem 
quality. Ecol. Indic., 12(1): 1-7. doi: 10.1016/j. ecolind.2011.06.018

Burke, L., Reytar, K., Spalding, M. \& Perry, A. 2011. Reefs at risk revisited. World Resources Institute, Washington DC, 114 pp

Chabanet, P., Bigot, L., Nicet, J.B., Durville, P., Massé, L., Mulochau, T., Russo, C., Tessier, E. \& Obura, D. 2016. Coral reef monitoring in the lles Eparses, Mozambique Channel (2011-2013). Acta Oecol., 72: 62-71.

Caras, T. \& Pasternak, Z. 2009. Long-term environmental impact of coral mining at the Wakatobi marine park, Indonesia. Ocean Coast. Manag., 52: 539-544.

Corvianawatie, C. \& Abrar, M.2018. Compatibility Of Oceanographic Conditions in Supporting Coral Reefs Ecosystem In Pari Island Coastal Water. J. Kelautan Nasional, 13: 155-161. doi: 10.155 78/jkn.v13i3.6322

Crain, C.M., Kroeke, K. \& Halpern, B.S. 2008. Interactive and cumulative effects of multiple human stressors in marine systems. Ecol. Lett., 11: 1304-1315. doi: 10.1111/j.1461-0248.20 08.01253.x

Dollar, S.J. 1982. Wave stress and coral communities structure. Coral Reef, 1: 71- 81.

English, S., Wilkinson, C. \& Baker, V. 1997. Survey manual for tropical marine resources. 2nd Ed. ASEAN-Australia Marine Science Project: Living Coastal Resources, Australian Institute of Marine Science, PMB No. 3, Townsville Mail Centre, Australia 4810, 390pp.

Fabinyi, M. 2008. Dive tourism, fishing and marine protected areas in the Calamianes Islands, Philippines. Mar. Policy, 32(6): 898-904. doi: 10.1016/j.marpol.2008.01.004

Fabricius, K.E. 2005. Effects of Terrestrial Runoff on the Ecology of Corals and Coral Reefs: Review and Synthesis. Mar. Poll. Bull., 50: 125-146.

Fox, H.E., Mous, P.J., Pet, J.S., Muljadi, A.H. \& Caldwell, R.L. 2005. Experimental assessment of coral reef rehabilitation following blast fishing. Conserv. Biol., 19: 98-107.

Gomez, E.D., Aliño, P.M., Yap, H.T. \& Licuanan, W.Y. 1994. A review of the status of Philippine reefs. Mar. Poll. Bull., 29(1-3): 62-68. doi: 10.1016/ 0025-326X(94)90427-8
Green, E.P., Mumby, P.J., Edwards, A.J. \& Clark, C.D. 2000. Remote Sensing Handbook for Tropical Coastal Management. In: Edwards, A.J. (ed.). Coastal Management Sourcebooks 3. UNESCO. $x+316$ pp. Paris (FR)

Jackson, J.B.C., Kirby, M.X., Berger, W.H., Bjorndal. K.A., Botsford, L.W., Bourque, B.J., Bradbury, R.H., Cooke, R., Erlandson, J., Estes, J.A., Hughes, T.P, Kidwell, S., Lange, C.B, Lenihan, H.S., Pandolfi, J.M., Peterson, C.H., Steneck, R.S., Tegner, M.J. \& Warner, R.R. 2001. Historical Overfishing and the Recent Collapse of Coastal Ecosystems. Science, New Series, 293(5530): 629-638.

Korpinen, S. \& Andersen, J.H. 2016 A Global Review of Cumulative Pressure and Impact Assessments in Marine Environments. Front. Mar. Sci., 3: 1-13. doi: 10.3389/fmars.2016. 00153.

Giyanto, Abrar, M., Hadi, T.A., Hafizt, M., Salatalohy, A. \& Iswari, M.Y. 2017. Status Terumbu Karang Indonesia. Puslit Oseanografi - LIPI. Jakarta.

Guan, Y., Hohn, S. \& Merico, A. 2015 Suitable Environmental Ranges for Potential Coral Reef Habitats in the Tropical Ocean. PLoS ONE, 10(6): e0128831. doi: 10.1371/journal.pone.0128831

Halid, N.H., Ahmad, Z., Kamarumtham, K., Saad, S., Khodzori, M.F.A., Hanapiah, M.F.M. \& Yusof, M.H., 2016. The effect of current on coral growth form in selected areas of Tioman Island, Pahang. Trans. Sci. Technol., 3(3): 393-402.

Hidaka, M. 2016. Life History and Stress Response of Scleractinian Corals. In Coral Reef Science. Hajime Kayanne (Ed) pp.1-24. doi: 10.1007/ 978-4-431-54364-0_1

Hughes, T.P., Maria, J.R., David, R.B., Daniela, C., Hoegh-Guldberg, O., McCook. L., Moltschaniwskyj, N., Morgan, S.P., Robert, S.S., \& Bette, W. 2007. Phase shifts, herbivory, and the resilience of coral reefs to climate change. Current Biol., 17(4): 360-365.

Limbu, S.M. \& Kyewalyanga, M.S. 2015. Spatial and temporal variations in environmental variables in relation to phytoplankton composition and biomass in coral reef areas around Unguja, Zanzibar, Tanzania. Springer Plus, 4(1): 1-18, doi: 10.1186/s40064-015-143 9-z

Kenchington, R.A., 1978. Visual surveys of large areas of coral reefs. In: D.R. Stoddart, D.R. \& Johannes, R.F. (Eds.). Coral Reefs: research method, Paris, Unesco. Pp. 149-162. 
Magris, R.A., Grech, A. \& Pressey, R.L. 2018. Cumulative Human Impacts on Coral Reefs: Assessing Risk and Management Implications for Brazilian Coral Reefs. Diversity 10(2):26. doi: $10.3390 / \mathrm{d} 10020026$

Mimura, N. ed. 2008. Asia-Pasific Coasts and Their Management, Springer: 379 p.

Markey, K.L., Abdo, D.A. Evans, S.N. \& Bosserelle, C .2016. Keeping It Local: Dispersal Limitations of Coral Larvae to the High Latitude Coral Reefs of the Houtman Abrolhos Islands. PLOS ONE, 11(1): e0147628. doi: 10.1371/journal.pone.0 147628

Monismith, S.G. 2007. Hydrodynamics of Coral Reefs. Ann. Rev. Fluid Mechanics, 39(1): 37-55. doi: 10.1146/ annurev.fluid.38.050304.092125

Moran, P.J., Johnso, D.B., Miller-Smith, B.A., Mundy, C.N., Bass, D.K., Davison, J., Miller, I.J. \& Thompson, A.A. 1990. A guide to the AIMS manta towing technique. Australian Institute of Marine Science, Townsville.

Muhammad, F., Hidayat, J.W. \& Mukid, M.A. 2013. Aplikasi Bio-Ekologi Makrobentos Sebagai Indikator Tingkat Kesuburan Tambak. J. Sains Matematika, 21(3): 75-83.

Munasik, Sabdono, A., Assyfa, A.N., Wijayanti, D.P., Sugiyanto, Irwani \& Pribadi. R. 2020. Coral transplantation on a multilevel substrate of Artificial Patch Reefs: effect of fixing methods on the growth rate of two Acropora species. Biodiversitas. 21(5): 1816-1822. doi: 10.13 057/biodiv/d210507

Munday, P.L., Dixson, D.L., Donelson, J.M., Jones, G.P., Pratchett, M.S., Devitsinac, G.V. \& Døvingd, K.B. 2009. Ocean acidification impairs olfactory discrimination and homing ability of a marine fish. Proc. Nat. Academy Sci., 106(6): 18481852. doi: 10.1073pnas.0809996106

Nazir, M. 2005. Metodologi Penelitian. Penerbit Ghalia. Bogor. Indonesia. 544 p

Nugraha, D.R.W. 2019. Pengaruh faktor hidrooseanografi terhadap pertumbuhan dan tingkat kelangsungan hidup (survival rate) hasil transplantasi terumbu karang jenis Acropora sp. di Perairan Paiton Probolinggo. Disertation UIN Sunan Ampel, Surabaya.

Nurulita, V.K., Purba, N.P., Mulyani, Y. \& Harahap, S.A. 2018. Pergerakan Larva Karang (Planula) Acropora di Kepulauan Seribu, Biawak, dan
Karimunjawa Berdasarkan Kondisi Oseanografi. J. Perikanan Kelautan IX(2):16-26.

Nybakken, J.W. 1992. Biologi Laut. Jakarta: PT Gramedia Pustaka Utama

Osborne, K., Dolman A.M., Burgess, S.C. \& Johns, K.A. 2011. Disturbance and the Dynamics of Coral Cover on the Great Barrier Reef (1995-2009). PLOS ONE, 6(3):e17516. doi: 10.1371/journal. pone.0017516

Pandolfi J.M. 2011 Historical Ecology of Coral Reefs. In: Hopley D. (eds) Encyclopedia of Modern Coral Reefs. Encyclopedia of Earth Sciences Series. Springer, Dordrecht. doi: 10.1007/978-90-4812639-2_94

Perera-Valderrama, S., Hernández-Arana, H., RuizZárate, M.Á., Alcolado, P.M., Caballero-Aragón, H., González-Cano, J., Vega-Zepeda, A. \& CobiánRojas, D. 2016. Condition assessment of coral reefs of two marine protected areas under different regimes of use in the northwestern Caribbean. Ocean Coast. Manag., 127:16-25.

Pratchett, M.S., McCowan D., Maynard, J.A. \& Heron, S.F. 2013. Changes in Bleaching Susceptibility among Corals Subject to Ocean Warming and Recurrent Bleaching in Moorea, French Polynesia. PLos One. doi: 10.1371/journal. pone.0070443.pp1-10.

Pratchett, M.S., Hoey, A.S. \& Wilson, S.K. 2014. Reef degradation and the loss of critical ecosystem goods and services provided by coral reef fishes. Curr. Opin. Environ. Sustain., 7:37-43. doi: 10.1016/j.cosust.2013.11.022

Rahmat, Yosephine \& Giyanto. 2001. Software Percent Cover Benthic Lifeform Versi 5.1. Pusat Penelitiaan dan Pengembangan Oseanologi. Lembaga IImu Pengetahuan Indonesia. Jakarta.

Richards, B.L., Williams, I.D., Vetter, O.J. \& William, G.J. 2012. Environmental factors affecting largebodied coral reef fish assemblages in the Mariana archipelago. PLoS ONE, 7(2):e31374. doi: 10.1371/journal.pone.00313745.

Riegl, B.M. \& Purkis, S.J. 2012. Dynamics of Gulf Coral Communities Observations and Modelsfrom the World's Hottest Coral Sea. In: Riegl, B.M. \& Purkis, S.J. (eds.), Coral Reefs of the Gulf : Adaptation to Climatic Extremes. Coral Reefs of the World 3, doi: 10.1007/978-94007-3008-3_5. 
Rifa'i, M.A. 2004. Kamus biologi cetakan ke-4, Jakarta Balai Pustaka, 59pages

Rogers. 2013. Review Article: Coral Reef Resilience through Biodiversity. Int. Scholarly Res. Notices, pp 1-18, doi: 10.5402/2013/739034.

Siregar, V. 2010. The bottom substrate shallow water mapping using the quick bird satellite imagery. J. IImu Teknol. Kelautan Tropis, 2(1): 19-30.

Suharti, R., Saktiawan, K.Y., Rachmad, B., Tryono, H. \& Zulkifli, D. 2018. Kajian Bioekologi Ikan Karang Chaetodontidae Sebagai Salah Satu Indikator Untuk Mendeteksi Kondisi Ekosistem Terumbu Karang Di Perairan Taman Nasional Kepulauan Togean, Sulawesi Tengah. J. Kelautan Perikanan Terapan, 1(1): 12-21

Suraji, Rasyid, N., Asri, S.K.H, Jannah, A.R., Wulandari, D.R., Saefudin, M., Ashari, M., Widiastutik, R., Kuhaja, T., Juliyanto, E., Afandi, Y.A., Wiyono, B., Syafrie, H., Handayani, S.N. \& Soemodinoto, A. 2015. Profil Kawasan Konservasi Provinsi Jawa Tengah. Jakarta: Kementerian Kelautan dan Perikanan. Direktorat Konservasi Kawasan dan Jenis Ikan. Direktorat Jenderal Kelautan, Pesisir dan PulauPulau Kecil, Kementerian Kelautan dan Perikanan

Sugianto, D.N., Zainuri, M., Darari, A., Suripin, S.D. \& Yuwono, N. 2017. Wave height forecasting using measurement wind speed distribution equation in Java Sea, Indonesia. Int. J. Civ. Eng. Technol., 8(5):604-619.

Supriharyono. 2007. Konservasi Ekosistem Sumberdaya Hayati, Pustaka Pelajar Yogyakarta.

Swart, P.K. 2013. Coral Reefs: The canaries of the Sea, Rainforests of the Oceans. Nat. Educ. Knowled., 4(3): 5

Toruan, L.N.L., Soedharma, D. \& Dewi, K.T. 2013. Komposisi dan Distribusi Foraminifera Bentik di Ekosistem Terumbu Karang pada Kepulauan Seribu, J. Ilmu Teknol. Kel. Trop., 5(16): 1-16

Tjitrosomo, S.S. 2010. Botani Umum 4. 203pages. Bandung: Angkasa.
Vo, S.T., Pernetta, J.C. \& Paterson, C.J. 2013. Status and trends in coastal habitats of the South China Sea. Ocean. Coast. Manag., 85: 153-163.

Wenger, A.S., Whinney, J., Taylor, B. \& Kroon, F. 2016. The impacted individual and combined abiotic factors on daily otolith growth in a coral reef fish. Sci. Rep., 6: 28875. doi: 10.1038/srep288756.

Wibawa, I.G.N.A. \& Luthfi, O.M., 2017. Kualitas air pada ekosistem terumbu karang di Selat Sempu, Sendang Biru, Malang. J. Segara, 13(1): 25-35.

Widodo, J. 1999. Aplikasi Teknologi Penginderaan Jauh untuk Perikanan di. Indonesia. Prosiding Seminar Validasi Data Inderaja Untuk Bidang Perikanan. Jakarta. Indonesia.

Wisha, U.J., Ondara, K., Gemilang, W.A., Rahmawan, G. A., Dhiauddin, R. \& Ilham, I. 2019. Coral Reef Condition in Relation to Coral Reef Fish Abundances Before Mass Bleaching Event in Simeulue Islands, Aceh. Indonesian Fisheries Res. J., 25(2): 64-74. doi: 10.15578/ifrj.25.2. 2019.64-74

Wolanski, E., Richmond, R.H. \& McCook, L. 2004. A model of the effects of land-based, human activities on the health of coral reefs in the Great Barrier Reef and in Fouha Bay, Guam, Micronesia. J. Mar. Sys., 46:133-144.

Wong, P.P. 1993 Island tourism development in Peninsular Malaysia: environmental perspective. In: Wong P.P. (Ed.). Tourism vs environment: the case for coastal areas. Kluwer Academic Publishers. pp. 83-97.

Wooldridge, S.A. 2009. Water quality and coral bleaching thresholds: formalising the linkage for the inshore reefs of the Great Barrier Reef, Australia. Mar. Poll. Bull., 58: 745-751.

Yuningsih, A. \& Achmad, M. 2011. Potential energy of ocean current for electric power generation in coastal areas of East Flores, NTT. J. IImu Teknol. Kelautan Tropis, 3(1):13-25.

Yusuf, M. 2007. Kebijakan Pengelolaan Sumberdaya Pesisir dan Laut Kawasan Taman Nasional Karimunjawa Secara Berkelanjutan. Sekolah Pascasarjana Institut Pertanian Bogor. 